\title{
Plant communities along the Eerste River, Western Cape, South Africa: Community descriptions and implications for restoration
}

\author{
Authors: \\ Clifton S. Meek ${ }^{1,2}$ \\ David M. Richardson ${ }^{2}$ \\ Ladislav Mucina ${ }^{2,3}$ \\ Affiliations: \\ ${ }^{1}$ Percy FitzPatrick Institute, \\ DST/NRF Centre of \\ Excellence, University of \\ Cape Town, South Africa \\ ${ }^{2}$ Centre for Invasion \\ Biology, Department \\ of Botany and Zoology, \\ Stellenbosch University, \\ South Africa \\ ${ }^{3}$ Department of Environment \\ and Agriculture, Curtin \\ University, Australia \\ Correspondence to: \\ David Richardson \\ Email: \\ rich@sun.ac.za \\ Postal address: \\ Private Bag X1, Matieland \\ 7602, South Africa \\ Dates: \\ Received: 20 June 2012 \\ Accepted: 25 Oct. 2012 \\ Published: 15 Mar. 2013 \\ How to cite this article: \\ Meek, C.S., Richardson, D.M. \\ \& Mucina, L., 2013, 'Plant \\ communities along the \\ Eerste River, Western Cape, \\ South Africa: Community \\ descriptions and implications \\ for restoration', Koedoe \\ 55(1), Art. \#1099, 14 pages. \\ http://dx.doi.org/10.4102/ \\ koedoe.v55i1.1099 \\ Note: \\ Additional supporting \\ information may be found \\ in the online version of \\ this article as an Online \\ Appendix: http://dx.doi. \\ org/10.4102/koedoe. \\ v55i1.1099-1.

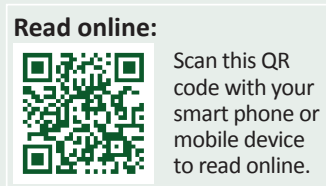

Riparian plant communities fulfil many functions, including the provision of corridors linking protected areas and other zones of high conservation value. These habitats across much of South Africa's Cape Floristic Region, especially in the lowlands, have been heavily impacted and degraded by human activities. There is increasing interest in the restoration of degraded riparian zones and the ecosystem services they provide to enhance the conservation value of landscapes. Previous studies of riparian vegetation in the Cape Floristic Region focused on pristine headwater systems, and little is known about human-impacted communities that make up most of the riparian vegetation in downstream areas. More information is needed on the composition of these plant communities to establish a baseline for management intervention. The riparian zone of the Eerste River in South Africa's Western Cape province provides a good opportunity to study the features of riparian vegetation along the entire gradient, from pristine vegetation in a protected area through different levels of humanmediated degradation. Riparian vegetation was surveyed in 150 plots along the entire length of the Eerste River (ca. $40 \mathrm{~km}$ ). Data were analysed using the vegetation classification and analysis software package JUICE. Final groupings were plotted onto a two-dimensional detrended correspondence analysis plane to check the position of the communities in the reduced multidimensional space. Ten distinct plant communities were identified, including several novel communities dominated by alien plant species. Descriptions of each plant community are presented. Diagnostic, constant and dominant species are listed and the major structural and ecological characteristics of each community are described.

Conservation implications: Major changes to hydrological and soil properties, nutrient dynamics and disturbance regimes and plant species composition along sections of the riparian zone mean that restoration of many of these habitats to their historic condition is not feasible. However, several native plant species that provide key ecosystem services persist in and adjacent to transformed communities, offering substantial opportunities for restoration to achieve certain goals.

\section{Introduction}

The flora of South Africa's Cape Floristic Region (CFR) is exceptionally diverse, with one of the highest levels of species diversity endemism of any flora in the world. Research on vegetation ecology in the Fynbos biome of the CFR has focused largely on aspects of the iconic Cape shrublands - mainly fynbos and renosterveld (e.g. Cowling 1992; Cowling, Richardson \& Mustart 1997; Linder 2003). Riparian vegetation in the Fynbos biome is, however, structurally and compositionally distinct from the surrounding Cape shrublands. The predominant vegetation type of riparian zones in the Western Cape has been variously named closed scrub fynbos (Campbell 1986; Cowling \& Holmes 1992; Cowling et al. 1997), hygrophilous mountain fynbos (Taylor 1978) and broad sclerophyllous closed scrub (Holmes et al. 2005; Kruger 1978). Other types, ranging from tall herblands to forests, may also occur in the riparian zone (Kruger 1978). True afrotemperate forest may develop in areas of steep topography that afford protection from fires (Manders \& Richardson 1992). Despite being recognised as a special vegetation type in the biome, riparian vegetation has been paid very little attention in the regional literature. Where it is discussed, it is usually in the context of the larger terrestrial matrix. Very few formal classifications of riparian vegetation in the Fynbos biome have been published (but see Prins, Holmes \& Richardson 2004; Sieben, Mucina \& Boucher 2009; Sieben \& Reinecke 2008) and none have looked at riparian communities outside relatively pristine headwater systems, which occur mostly in protected areas. 
Riparian communities in the CFR, especially those in the south-western part of the region, have been heavily impacted recently by human activities. Intensive land use in the lowlands has led to increased soil erosion and sedimentation, increased nutrient inputs, and altered hydrological regimes due to water impoundment and abstraction. In many cases, vegetation clearance for agriculture and urbanisation has included riparian vegetation. In addition, riverine corridors provide ideal conditions for the establishment, proliferation and spread of the many alien plants that were introduced to the region. The constant disturbance along rivers as a result of their dynamic hydrological nature and their ability to function as conduits for dispersal of propagules means that riparian zones are severely invaded worldwide (Foxcroft, Rouget \& Richardson 2007; Hood \& Naiman 2000; PlantyTabacchi et al. 1996). Positive feedback mechanisms promote rapid spread of aliens along riparian corridors through human-induced habitat alteration and increased propagule pressure (Richardson et al. 2007).

This combination of pressures on the natural environment has led to the establishment of novel ecosystems (sensu Hobbs et al. 2006) along the riparian corridors of the CFR. No corridors remain undisturbed in their lower reaches and it is unclear what the composition of historical plant communities in these downstream systems would have been (Brown 1998; Prins et al. 2004). These riparian ecosystems fulfil a range of useful functions in the Western Cape and there is increasing interest in conserving or restoring key ecosystem services in these zones. Intact riparian corridors in the CFR have also been identified as being important for migration and exchange of inland and coastal biotas in a human-dominated landscape in the face of global change (Rouget et al. 2003). Before sensible restoration efforts can be undertaken, more information is required on the composition of these ecosystems. The Eerste River provides a superb natural laboratory for the study of the changing dynamics of a river and its associated riparian habitats.

This study aimed to describe the plant communities along the entire length of the riparian corridor of the Eerste River in the Western Cape province to establish a baseline for management and future research. The 150 permanent plots established in this study (see also Meek, Richardson \& Mucina 2010) form a permanent transect with considerable potential for other studies of biotic and abiotic changes along a well-studied river situated close to a university. Another objective of this work was to identify native species that could be used in restoration efforts in disturbed riparian areas in the Fynbos biome.

\section{Research method and design \\ Study area}

The Eerste River originates in the Jonkershoek Mountains in the Western Cape, South Africa. It has a catchment area of $420 \mathrm{~km}^{2}$, and it is approximately $40 \mathrm{~km}$ long. The source of the river lies $60 \mathrm{~km}$ east of Cape Town at an altitude of $530 \mathrm{~m}$, from where it flows in a north-westerly direction towards the town of Stellenbosch. At Stellenbosch, the river takes an abrupt turn, flowing southwards until it meets the Atlantic Ocean in False Bay near the town of Macassar (Figure 1). The river is influenced by flows from several tributaries along its route, with the bank-to-bank width averaging $5 \mathrm{~m}$ near the headwaters and $14 \mathrm{~m}$ in the lower river zone. The average gradient of the river ranges from $24 \mathrm{~m} / \mathrm{km}$ in the mountain stream zone to as little as $2 \mathrm{~m} / \mathrm{km}$ in the lower reaches of the river (King 1981).

The geology of the Eerste River catchment is composed of Table Mountain Sandstone in the upper reaches and Malmesbury Shale and Cape Granite of the Bokkeveld Group in the lower reaches. Low-lying coastal plain areas are composed of aeolian sands (Brown \& Dallas 1995). The catchment of the river lies entirely within a Mediterraneanlike climate zone, which has cool, wet winters and hot, dry summers. Annual rainfall averages range from more than $3000 \mathrm{~mm}$ (Sieben et al. 2009) in the upper reaches of the river to around $570 \mathrm{~mm}$ in the lower reaches. About $80 \%$ of this precipitation falls in winter downpours, with only $7 \%$ of the annual rain occurring between December and March (King 1981).

As with most rivers in areas of concentrated development, the Eerste River has undergone dramatic changes in the years since European settlement. Intensive human use of the river dates back to as early as 1697 , with over-abstraction becoming a problem as early as 1862 . Indigenous trees were used for firewood and timber in the early days of European settlement and were later replaced by plantings of English oaks (Quercus robur) (Brown \& Magoba 2009). Currently, the landscape surrounding the Eerste River supports a number of land uses, including nature conservation, commercial forestry, residential use, various forms of agriculture (vineyards, orchards and crop production) and communal grazing.

Approximately the first $6 \mathrm{~km}$ of the upper river reaches are bordered by natural vegetation within the Hottentots Holland and Jonkershoek Nature Reserves, and is relatively

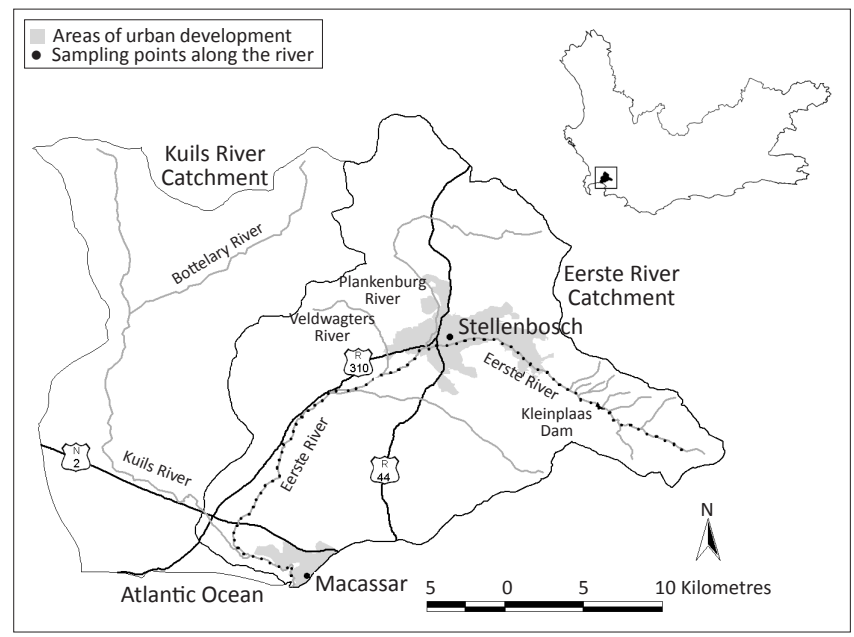

FIGURE 1: The location of the Eerste River in the Western Cape, South Africa. 
unaffected by human influence. Although forestry plantations of Pinus radiata exist in portions of the landscape in the Jonkershoek Nature Reserve, 'a wide buffer zone of natural fynbos vegetation has been maintained between the river and plantation areas' (Meek et al. 2010). Since 1981, the upper reach of the river has been regulated by the Kleinplaas Dam, above which the Eerste River is perennial (Department of Water Affairs and Forestry [DWAF] 2004). During summer months, a municipal weir above the dam diverts the river's flow to the Ida's Valley Dam, which supplies drinking water and water for domestic use to the town of Stellenbosch (Brown \& Dallas 1995). In order to provide compensation releases for downstream users, this flow is replaced with water from the Theewaterskloof Dam through an interbasin transfer scheme. Water from the Theewaterskloof Dam contains high sediment loads, significantly reducing the water quality and negatively affecting downstream biotas in the Eerste River (Brown \& Magoba 2009).

'Stellenbosch (human population ca. 117,000) is the main urban area along the river, with additional urban development present in Macassar' (Meek et al. 2010). Historically, the river through Stellenbosch was notably shallower and more flood prone than it is today, containing heavily wooded banks and numerous islands. Considerable canalisation of the river through the town of Stellenbosch has all but eliminated the river's historic flood regime through this area (Brown \& Magoba 2009). The banks of the river through Stellenbosch are currently both deep and heavily confined.

Just south of Stellenbosch, the Eerste River is joined by the Plankenburg River. Water is abstracted at this point, near the confluence with the Blouklip River, and (at lower levels by by owners of riparian properties) along most of its length. Treated municipal effluent enters the river through the Veldwagters tributary. Below the confluence of the Veldwagters and Eerste Rivers, treated effluent is an important component of river flow in summer. This makes the river largely perennial in downstream areas.

\section{Field sampling}

Vegetation of the riparian zone was surveyed along the entire length of the Eerste River, from the headwaters to just upstream of the estuary. All fieldwork was performed from mid-September through mid-December (i.e. in spring) 2008 in order to capture the greatest number of herbaceous species. Vegetation plots were paired at intervals of $500 \mathrm{~m}$ along both banks of the river and plot edges were extended to bankfull margins. A total of 150 plots were surveyed and locations were recorded using a Garmin GPS Map76 handheld global positioning system. Plot sizes were adjusted depending upon structure of the plant community at each plot location in order to capture all regularly occurring species. Herb-dominated communities were sampled with plots of $20 \mathrm{~m}^{2}$, shrublands / thicket with $50 \mathrm{~m}^{2}$ plots, and forest communities with $100 \mathrm{~m}^{2}$ plots. The decision on the plot size was based upon values suggested in Westhoff and Van der Maarel (1973).

All plant species within a plot were recorded, and height and absolute cover for each species was estimated. Species were determined to be native or alien following the criteria of Pyšek et al. (2004) and using published floras including Goldblatt and Manning (2000), Henderson (2001) and Bromilow (2005). Species that could not be identified in the field were collected and labelled, and identifications were later made at the Bolus Herbarium, University of Cape Town. All species determinations were verified by the herbarium curator (Meek et al. 2010), and collections have been archived at the Centre for Invasion Biology at Stellenbosch University (http://academic.sun.ac.za/cib/). The nomenclature of the plant names follows Goldblatt and Manning (2000), except for Searsia (see Moffett 2007).

Surface soil samples collected from each plot were air dried and the $\mathrm{pH}$ was measured using a calibrated $\mathrm{pH}$ meter in 10-g samples of soil suspended in $25 \mathrm{~mL}$ of potassium chloride solution. Soil cation concentrations of sodium, calcium, magnesium, and potassium were measured using ammonium acetate extraction, and phosphorous was measured using the Bray II method for samples with a $\mathrm{pH} \leq 6.9$ (Bray \& Kurtz 1945) and the Olsen method (Olsen et al. 1954) for samples with a $\mathrm{pH}>7$. Total carbon content (Walkley-Black method; Walkley 1935) and electrical resistance were also measured.

\section{Vegetation analysis and presentation}

Vegetation data comprising 150 sample plots were classified by beta-flexible clustering $(\beta=-0.25)$, using square root transformation and Manhattan distances as the resemblance measure to calculate distance between plots. The result of the clustering was translated into a structured relevé table using the software package JUICE version 7.0 (Tichý, Chytrý \& Zelený 2009). Vegetation data recorded per vertical layer were used to assure that both floristic and structural components of vegetation composition would be considered by the classification. Fidelity values were calculated for each of the resulting clusters, and the species in each of the columns of the synoptic table constructed by JUICE were sorted by fidelity using the phi coefficient of association (cut level of 0.35; L. Tichý, pers. comm., 16 Mar. 2009). The structured synoptic table was then translated back into a relevé table and inspected for plausibility (interpretability) of the resulting clusters. Clusters were further split or combined until desired resemblance and homogeneity criteria were reached. Interpretability of clusters with respect to field knowledge of the plant communities factored heavily in the decision on the final make-up of clusters. The final 10 clusters were plotted on a two-dimensional ordination plot of the detrended correspondence analysis (DCA; Hill \& Gauch 1980) using the ecological software package Canoco 4.5 (Ter Braak \& Šmilauer 2002) to visualise the level of 'spatial' separation (relative to the ordination plane) of the classification. 
Descriptions of each plant community were compiled. These list diagnostic, constant and dominant species (alien species are marked using an asterisk), and provide a narrative describing the major structural and ecological characteristics of the community. Diagnostic species were determined using the phi coefficient of association between species and vegetation units as a measure of fidelity (Chytrý et al. 2002). Species were considered to be diagnostic if they had a phi coefficient of 0.35 or higher. Constant taxa are those that occurred in at least $35 \%$ of relevés for a given community, whilst dominant species are those that had a cover value of $45 \%$ or greater in at least $5 \%$ of the relevés. A species binomial system was used in naming the communities, with one dominant and one diagnostic species being selected for the names.

\section{Results \\ Plant communities}

Ten distinct plant communities were identified. The floristic and structural composition of the communities is represented in the structured relevé table (Table 1). A list of all species encountered in the vegetation plots appears as Online Appendix 1.

\section{Cunonia capensis-Brachylaena neriifolia community}

Abbreviated name: Cunonia community (Figure 2a).

Diagnostic species: Cunonia capensis, Brachylaena neriifolia, Ilex mitis, Schoenoxiphium lanceum, Todea barbara, Blechnum capense, Cassine schinoides, Maytenus acuminata, Aristea capitata, Rapanea melanophloeos, Metrosideros angustifolia, Podalyria calyptrata, Blechnum punctulatum, Brabejum stellatifolium, Erica caffra, Ischyrolepis subverticillata, Pteridium aquilinum, Pellaea calomelanos, Elegia capensis, Cliffortia cuneata, Diospyros glabra, Asparagus scandens, Cassytha ciliolate.

Constant taxa: M. angustifolia, I. mitis.

Dominant species: C. capensis, R. melanophloeos, P. aquilinum, B. stellatifolium.

The Cunonia community occurs at altitudes of $262 \mathrm{~m}-496 \mathrm{~m}$, primarily where there has been no disturbance on lands immediately adjacent to the riparian zone. Rock cover estimates range from $10 \%-80 \%$, with an average of $42 \%$. Very little soil is present amidst the rock and tree roots. Where soils are present, they are sand or gravel with a low $\mathrm{pH}$ (average $=4.5$ ), low nutrient content, and high resistivity (i.e. low electrical conductivity). This community is characterised by a tall tree stratum $(6 \mathrm{~m}-13 \mathrm{~m})$ with an average cover of $72 \%$. This stratum is dominated by C. capensis, I. mitis, $M$. angustifolia and B. stellatifolium. Less common tree species in this stratum include C. schinoides, Platylophus trifoliatus, Maytenus oleoides and R. melanophloeos. A tall shrub stratum $(3 \mathrm{~m}-6 \mathrm{~m})$ grows below this, and has an average cover of $61 \%$. It is dominated by $B$. neriifolia and B. stellatifolium, although $M$. acuminata and $M$. angustifolia are also common in this stratum. This combination of tall tree and shrub strata creates a fully closed canopy above the forest floor. A herb stratum $(<1.5 \mathrm{~m})$, with an average cover of $29 \%$ and dominated by ferns, is the typical understorey of this community. Common understorey species include B. capense, B. punctulatum, T. barbara and S. lanceum. Structurally and floristically, this community is similar to the $R$. melanophloeos $-C$. capensis community described by McDonald (1988). It should be noted that this community was completely devoid of alien vegetation, with the exception of a single Acacia melanoxylon sapling present in one relevé. This relevé is adjacent to a bridge used by forestry vehicles, suggesting that the A. melanoxylon seed may have been introduced into the habitat by a passing vehicle.

\section{Brabejum stellatifolium-Metrosideros angustifolia community}

Abbreviated name: Brabejum community (Figure 2b).

Diagnostic species: M. angustifolia, B. stellatifolium, Virgilia oroboides, I. mitis, P. aquilinum, Freylinia lanceolata, E. caffra, Halleria elliptica, Rubus pinnatus, Psoralea aphylla, Phylica pubescens, Pentameris thuarii, P. calyptrate.

Constant taxa: Searsia angustifolia, Olea europaea subsp. africana, Kiggelaria africana, B. neriifolia, Prionium serratum, Pittosporum undulatum, D. glabra.

Dominant species: B. stellatifolium, F. lanceolata, P. serratum.

The Brabejum community can be found at altitudes from $228 \mathrm{~m}$ to $400 \mathrm{~m}$, on sandy soils with low $\mathrm{pH}$ (average $=4.3$ ), low resistivity and low nutrient content. This community tends to be interspersed with the Cunonia community where it occurs at altitudes between $228 \mathrm{~m}$ and $262 \mathrm{~m}$, above which the Cunonia community dominates. The amount of exposed rock ranges from $2 \%$ to $90 \%$, with an average of $35 \%$. The vegetation is composed primarily of an almost impenetrable layer of shrubs (up to $5 \mathrm{~m}$ ), with an average cover of $96 \%$. This stratum is dominated by B. stellatifolium, which occurs in every relevé. Interspersed with the B. stellatifolium in this layer are M. angustifolia, F. lanceolata, I. mitis, E. caffra and $P$. calyptrata, amongst others. P. serratum often grows along the water's edge. Above this stratum there is sometimes an emergent tree layer (up to14 $\mathrm{m}$ ) with an average cover of $11 \%$. The dominant species in this stratum is $V$. oroboides. A herb stratum dominated by $P$. aquilinum provides the understorey in this community, with an average cover of $15 \%$. Whilst this community is composed primarily of native species, a number of alien species have managed to invade, including P. undulatum and Acacia saligna. Structurally and floristically, this community has many similarities to the K. africana - B. stellatifolium community described by Prins et al. (2004), the H. elliptica - B. stellatifolium community described by McDonald (1988) and the Restio gaudichaudianus - M. angustifolia community described by Van Wilgen and Kruger (1985). 


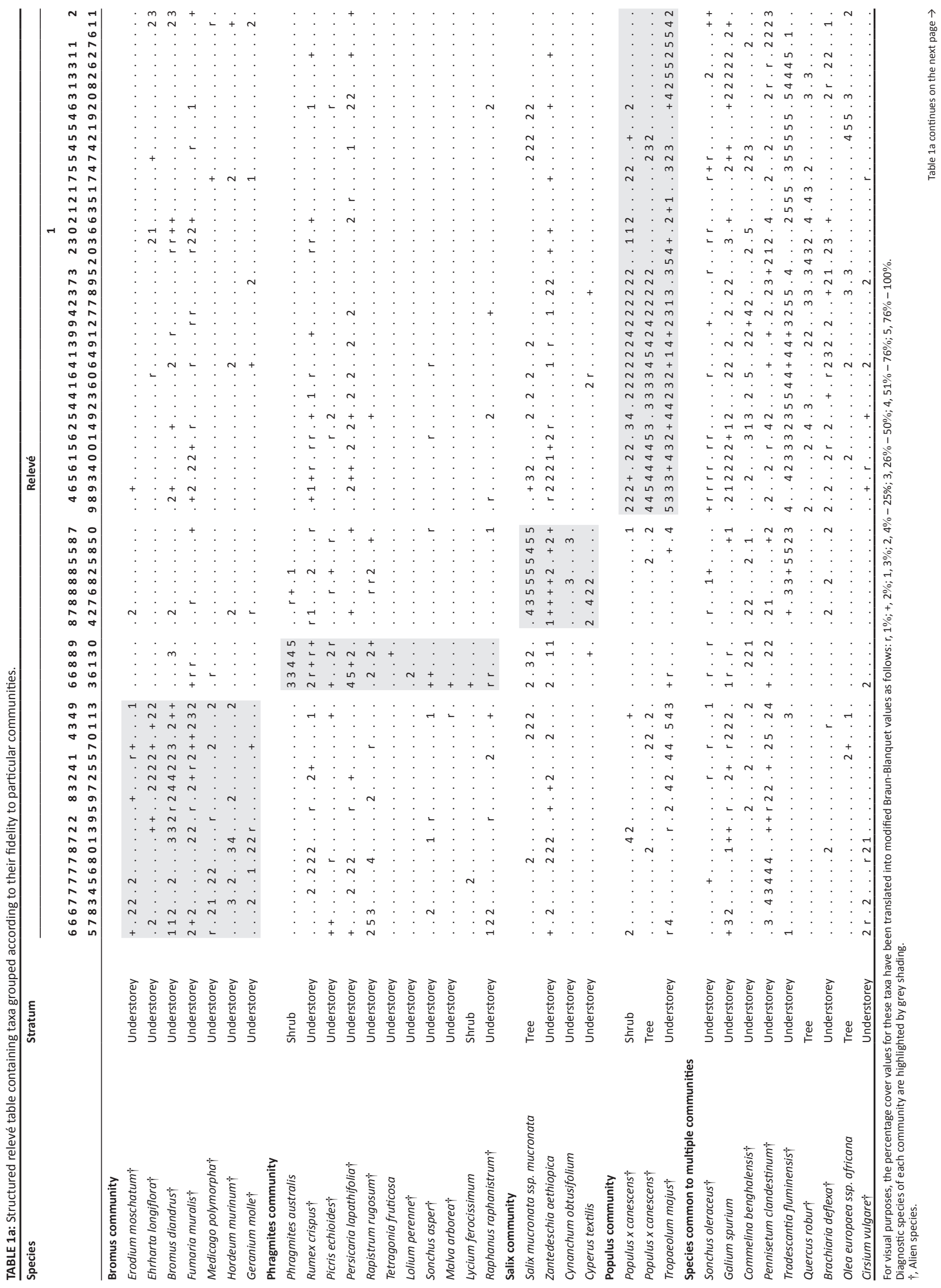




\section{Sporobolus africanus-Stoebe plumosa community}

Abbreviated name: Sporobolus community (Figure 2c).

Diagnostic species: Stoebe plumosa, R. pinnatus, Sporobolus africanus, Juncus lomatophyllus, Paspalum urvillei*, Passerina corymbosa, Searsia tomentosa, Cliffortia strobilifera, A. saligna*, Juncus effuses.

Constant taxa: S. angustifolia, O. europaea subsp. africana, D. glabra.

Dominant species: S. africanus.

The Sporobolus community occurs along the banks of the Kleinplaas Dam at an altitude of 277 m. It is represented here by only two relevés. This community is dominated by S. africanus, which forms its own stratum, $1.0 \mathrm{~m}$ high and with an average cover of $53 \%$. S. angustifolia and C. strobilifera emerge from this stratum, reaching $2 \mathrm{~m}$ in height, whilst $S$. plumosa and $R$. pinnatus form a low stratum up to $0.5 \mathrm{~m}$. Less prominent species found within this community include P. urvillei, J. lomatophyllus and D. glabra, amongst others. Whilst $P$. serratum grows in dense patches along some areas of the Kleinplaas Dam, it was not captured in either of these relevés.

\section{Quercus robur-Cinnamomum camphora community}

Abbreviated name: Quercus community (Figure 2d).

Diagnostic species: Cinnamomum camphora*, Ligustrum ovalifolium*, Acacia longifolia*, Syzygium australe*, Acacia elata*, Q. robur*, P. undulatum*, Quercus palustris*, Agapanthus africanus (native, but here not in original habitat).

Constant taxa: B. stellatifolium, Commelina benghalensis*, Acacia mearnsii ${ }^{*}$, Tradescantia fluminensis*, O. europaea subsp. africana, S. angustifolia, K. africana, P. serratum, M. angustifolia, Bromus diandrus*, Briza maxima*, Brachiaria deflexa, Ageratina adenophora*.

Dominant species: Q. robur*, P. serratum, B. stellatifolium.

The Quercus community is the most prominent riparian plant community of urban areas in and around Stellenbosch, occurring at altitudes between $81 \mathrm{~m}$ and $225 \mathrm{~m}$. Soils are sandy and mildly acidic (average $\mathrm{pH}=5.08$ ), with low resistivity and moderate nutrient content. Exposed rock ranges from $0 \%$ to $80 \%$, with an average of $18 \%$. This is the most diverse of the Eerste River plant communities, thanks in part to the extraordinary number of alien species that have been introduced into the area. However, this community also maintains high native-species diversity relative to the other alien-dominated communities. Absolute cover of alien species averages $123 \%$, whilst the absolute cover of native species averages $73 \%$. Dominating the tree stratum $(5 \mathrm{~m}-21 \mathrm{~m})$ in this community is $Q$. robur. The alien species C. camphora, Eucalyptus camaldulensis and A. mearnsii play a secondary role in the canopy, as do the native species O. europaea subsp. africana, I. mitis and M. angustifolia. Average 


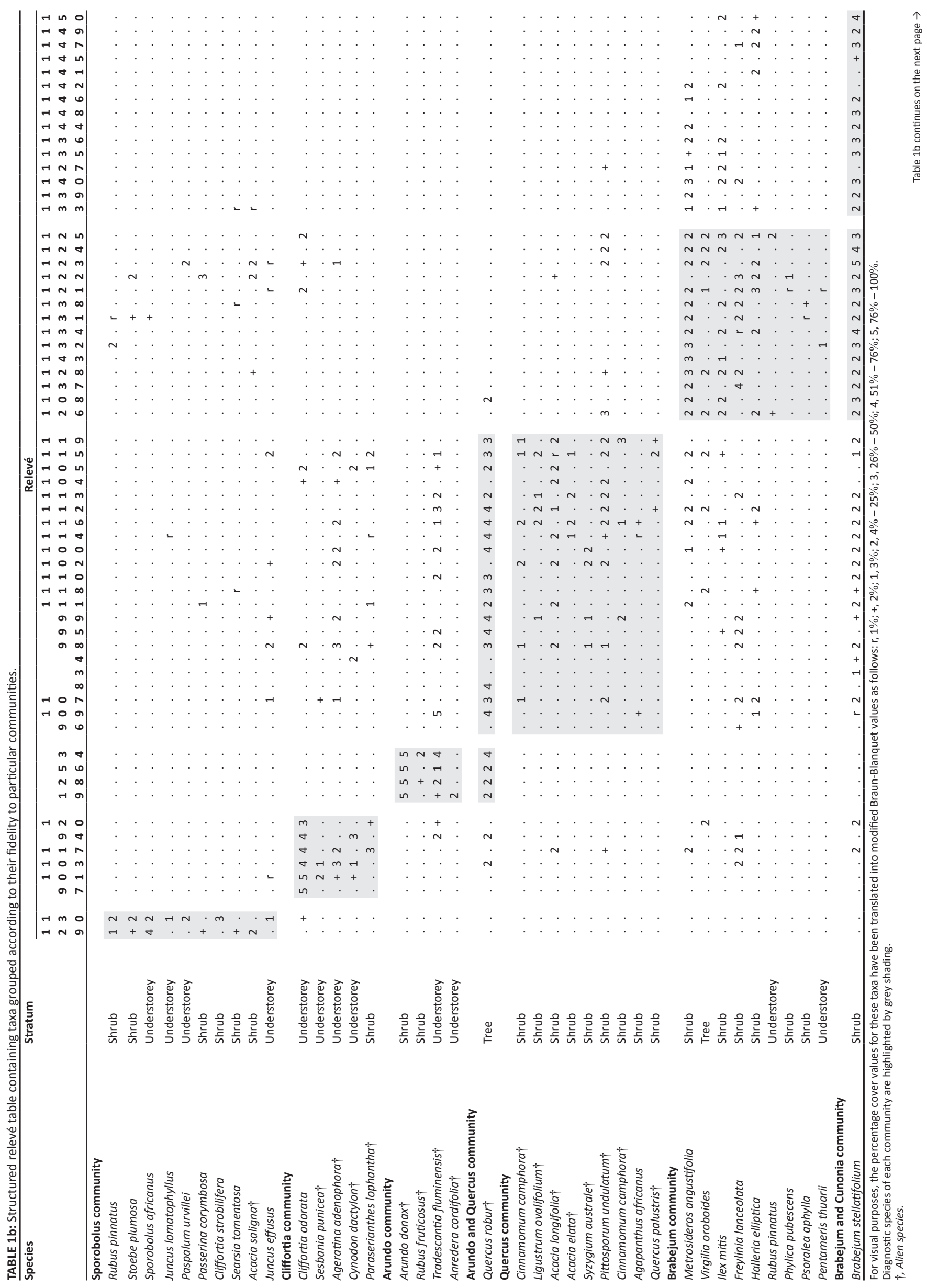




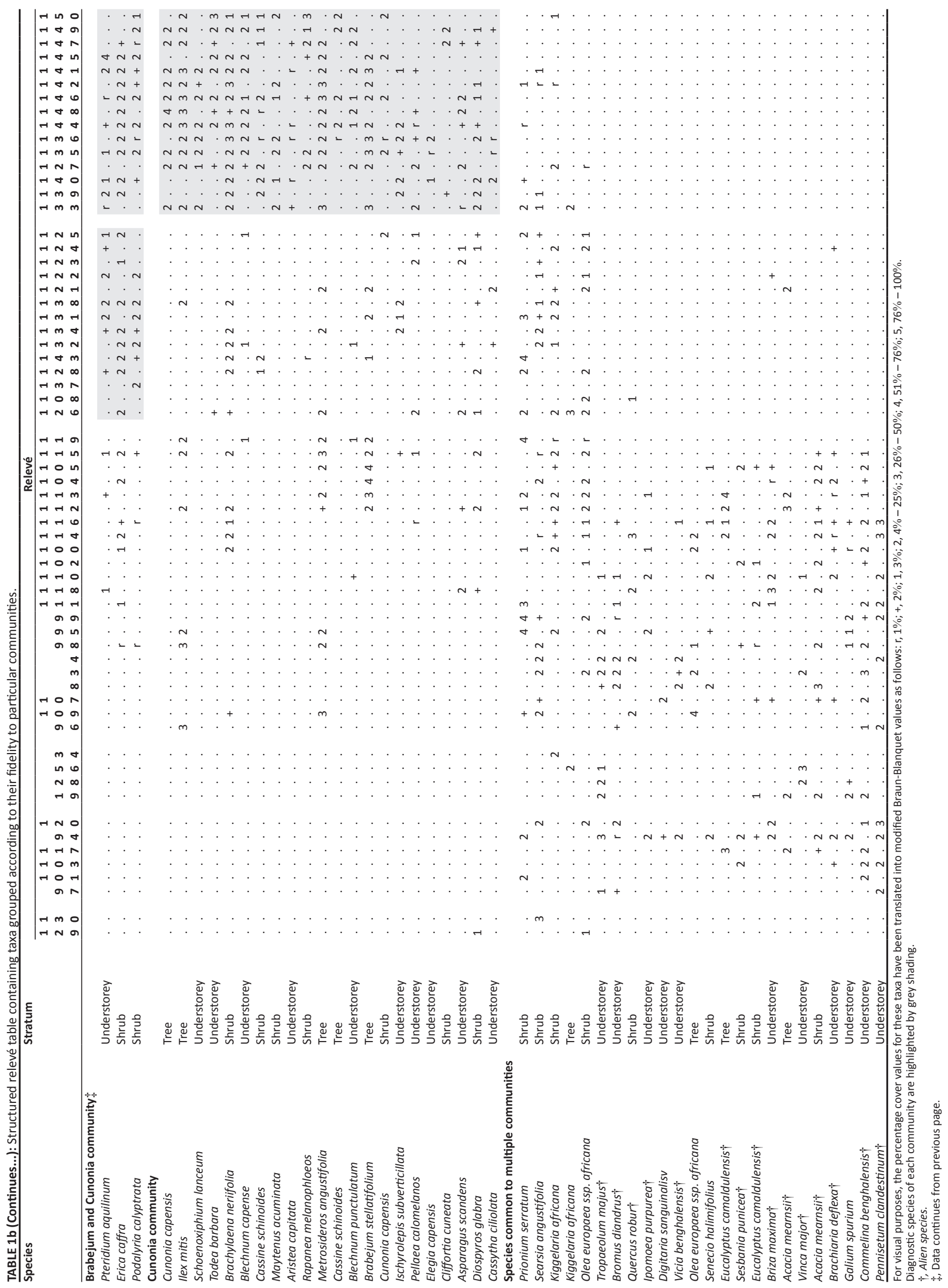


cover in this stratum is $67 \%$. Below the tree stratum is a diverse shrub stratum $(1.5 \mathrm{~m}-5 \mathrm{~m})$ dominated by the natives $P$. serratum and B. stellatifolium, with an average cover of $68 \%$. Other native species that commonly occur in this stratum are O. europaea subsp. africana, S. angustifolia, and K. africana. Alien species common to this stratum include C. camphora, L. ovalifolium, A. mearnsii, A. longifolia and P. undulatum. Dominating the understorey are alien T. fluminensis and Pennisetum clandestinum. Other common understorey alien species include B. maxima, C. benghalensis and A. adenophora. This stratum is sparser than the shrub and tree strata, with an average cover of $49 \%$.

\section{Cliffortia odorata-Ageratina adenophora community}

Abbreviated name: Cliffortia community (Figure 2e).

Diagnostic species: Cliffortia odorata, Sesbania punicea*, A. adenophora*, Cynodon dactylon, Paraserianthes lophantha*.

Constant taxa: P. clandestinum ${ }^{*}$, C. benghalensis ${ }^{*}$, F. lanceolata, B. diandrus*.

Dominant species: C. odorata.

A dense growth of C. odorata (up to $1.5 \mathrm{~m}$ ) is the defining component of this community, which occurs at altitudes from $114 \mathrm{~m}$ to $225 \mathrm{~m}$ on sandy soils with moderate resistivity, low nutrient content and an average $\mathrm{pH}$ of 5.2. Often interspersed with $C$. odorata are the alien species A. adenophora, C. benghalensis, P. clandestinum and in several relevés, small saplings of $S$. punicea. Emergent through this ground cover are shrubs (up to $4 \mathrm{~m}$ ) such as F. lanceolata and $P$. lophantha, providing a cover ranging from $0 \%$ to $74 \%$, with an average of $35 \%$. This community generally lacks a tree stratum, although in two relevés it contained a relatively open canopy of alien trees, including E. camaldulensis, Q. robur and A. mearnsii. This community is possibly identical to the C. odorata shrublands described by Sieben (2003).

\section{Populus x canescens-Tropaeolum majus community}

Abbreviated name: Populus community (Figure 3a).

Diagnostic species: Populus $x$ canescens*, Tropaeolum majus*.

Constant taxa:T.fluminensis*, Galium spurium, P. clandestinum*, B. deflexa, Zantedeschia aethiopica, Sonchus oleraceus*, Q. robur*.

Dominant species: T. fluminensis ${ }^{*}$, T. majus ${ }^{*}$, P. $x$ canescens ${ }^{*}$, Q. robur*, O. europaea subsp. africana, E. camaldulensis*, C. benghalensis*.

Of all the communities described here, the Populus community is by far the most widespread along the Eerste River, accounting for close to a third of all relevés. It is found primarily adjacent to agricultural lands at altitudes between $6 \mathrm{~m}$ and $162 \mathrm{~m}$. Soils are sandy and mildly acidic (average $\mathrm{pH}=5.48$ ), with low resistivity and high nutrient content. This community has the highest absolute cover of alien species of all the Eerste River plant communities, whilst the average absolute cover of native species is only $27 \%$. Dominating the tree stratum $(5 \mathrm{~m}-22 \mathrm{~m})$ in this community is $P$. $x$ canescens, although $E$. camaldulensis or $Q$. robur replace $P$. $x$ canescens as the dominant species in some relevés. Other prominent tree species in this community include A. mearnsii and Salix babylonica. The only native tree species that seem to have maintained a foothold in some areas are O. europaea subsp. africana and, to a lesser extent, K. africana and Salix mucronata subsp. mucronata. The tree canopy is almost never closed in this community ( $63 \%$ cover on average), allowing for enough light to promote growth of a herb stratum $(<1 \mathrm{~m})$ with an average cover of $97 \%$. Dominating this understorey are T. fluminensis and T. majus, both of which form dense mats of vegetation along the forest floor, which makes it difficult for competing plants to germinate. Other common understorey species include $B$. deflexa, $C$. benghalensis and P. clandestinum, as well as the native species G. spurium and Z. aethiopica. The shrub stratum $(1 \mathrm{~m}-4 \mathrm{~m})$ is generally sparse (average cover of $22 \%$ ) and is dominated by young $P$. $x$ canescens.
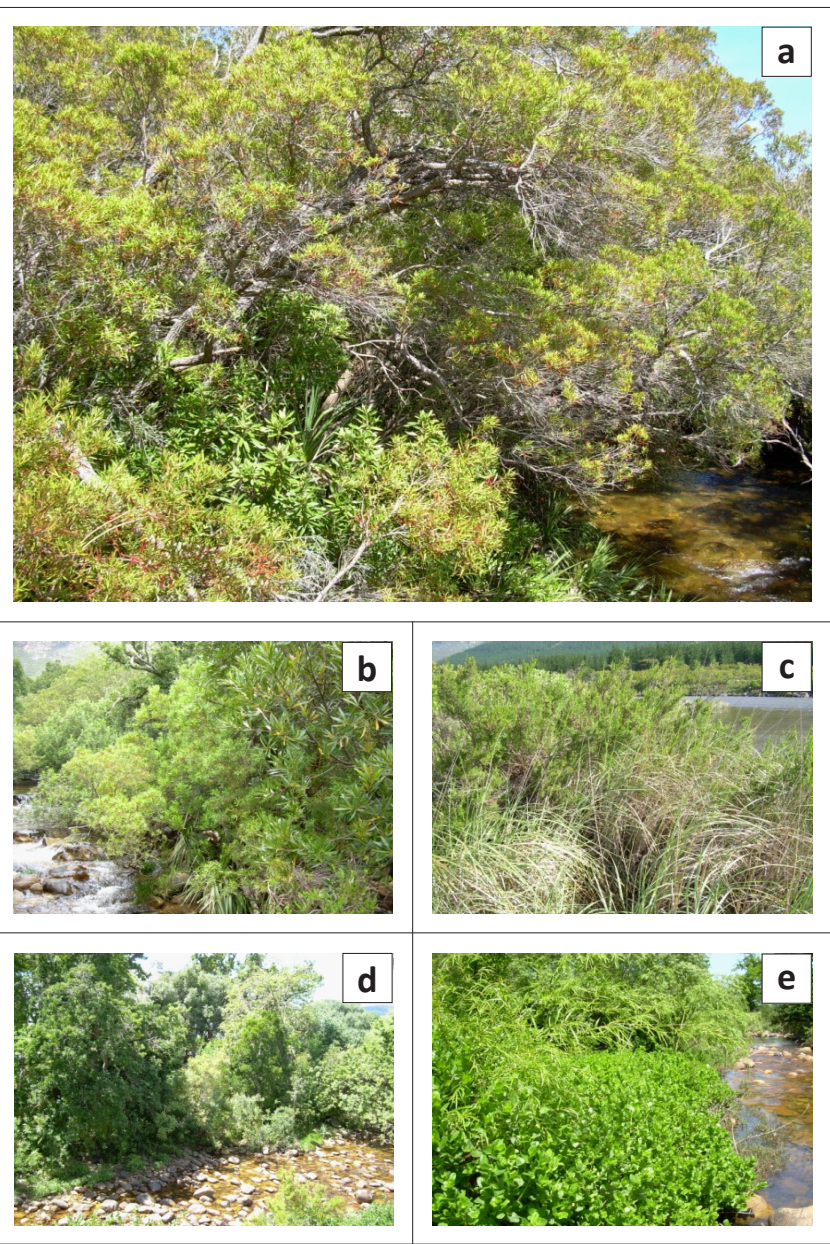

FIGURE 2: Plant communities along the upper reaches of the Eerste River (e.g. primarily upstream of the Plankenburg River confluence): (a) Cunonio community showing tall canopy of Metrosideros angustifolia with Brachylaena neriifolia and Prionium serratum in the undergrowth; (b) Brabejum community showing shrubby Brabejum stellatifolium and Metrosideros angustifolia with Prionium serratum growing along the river bank; (c) Sporobolus community with Sporobolus africana in the foreground and Cliffortia strobilifera in the background next to the Kleinplaas Dam; (d) Quercus community. Brabejum stellatifolium mixes with Pittosporum undulatum and Eucalyptus camaldulensis in the shrub layer with a canopy of Quercus robur and Ilex mitis and (e) Cliffortia community showing dense growth of Cliffortia odorata with Freylinia lanceolata above. 


\section{Bromus diandrus-Erodium moschatum community}

Abbreviated name: Bromus community (Figure 3b).

Diagnostic species: Erodium moschatum*, Ehrharta longiflora, B. diandrus* ${ }^{*}$ Fumaria muralis ${ }^{*}$, Medicago polymorpha* ${ }^{*}$ Hordeum murinum*, Geranium molle*.

Constant taxa: P. clandestinum*, G. spurium, T. majus*, Z. aethiopica, Echium plantagineum*.

Dominant species: B. diandrus*, P. clandestinum*, T. majus*, Rapistrum rugosum*.

The Bromus alien grassland community occurs at altitudes from $6 \mathrm{~m}$ to $114 \mathrm{~m}$ in heavily disturbed areas along the river, primarily downstream of Stellenbosch and adjacent to agricultural or communal grazing lands. It generally does not occur as a continuous unit, but rather in isolated patches interspersed amongst other communities. Soils are sandy, with low resistivity, neutral $\mathrm{pH}$ (average $=6.11$ ), and high nutrient content. This plant community is dominated by nonnative grasses and herbs and is unique amongst the riparian communities represented here for its lack of a shrub or tree stratum. Common species found within this community include the annual grasses B. diandrus, E. longiflora and $H$. murinum, as well as the perennial grass $P$. clandestinum. Herbs common to this community include the aliens E. moschatum, T. majus and E. plantagineum, as well as the native species G. spurium and Z. aethiopica. Dwarf versions of many of these species can be found in heavily grazed areas along the river, where a majority of the species have been pruned to within a few centimetres off the ground. $P$. clandestinum does particularly well in these areas owing to its creeping, mat-forming nature. Very little bare ground is present within this community, which has an average cover of $96 \%$.

\section{Arundo donax-Tradescantia fluminensis community}

Abbreviated name: Arundo community (Figure 3c).

Diagnostic species: Arundo donax*, T. fluminensis*, Rubus fruticosus*, Q. robur*, Anredera cordifolia*.

Constant taxa: T. majus*, Vinca major*, G. spurium.

Dominant species: A. donax*, T. fluminensis*, Q. robur*.

The Arundo community occurs within an altitudinal range of $15 \mathrm{~m}-53 \mathrm{~m}$, adjacent to agricultural lands downstream of Stellenbosch. Soils are sandy, with low resistivity, low $\mathrm{pH}$ (average $=4.45$ ) and unusually high phosphorus and potassium content. Species diversity is particularly low, with a mean of nine species per $50 \mathrm{~m}^{2}$ quadrat. As with the Bromus community, this community occurs primarily in isolated patches distributed amongst other downstream communities. The defining component of this community is the dense stands of the alien species $A$. donax (up to $6 \mathrm{~m}$ ), within which very few, if any, native species are able to survive. The thicket of $A$. donax emerges above a herbaceous stratum (up to $0.6 \mathrm{~m}$ ) of other alien species, including $V$. major, T. majus and T. fluminensis, as well as the weedy native species G. spurium. The tree K. africana was the only other native species found growing within this community. The alien herbaceous vine $A$. cordifolia is often found twining up the $A$. donax stalks, whilst $Q$. robur creates a canopy up to $13 \mathrm{~m}$ tall above the $A$. donax thicket. The tree stratum has a relatively low cover (average 26\%) compared to the herb (44\%) and shrub strata (95\%).

\section{Phragmites australis-Persicaria lapathifolia community}

Abbreviated name: Phragmites community (Figure 3d).

Diagnostic species: Phragmites australis, Persicaria lapathifolia*, Rumex crispus*, Helminthotheca echioides*, R. rugosum*, Tetragonia fruticosa, Lolium perenne*, Sonchus asper*, Lycium ferocissimum, Malva arborea*, Raphanus raphanistrum*, C. strobilifera.

Constant taxa: Z. aethiopica, S. mucronata subsp. mucronata, P. clandestinum*, G. spurium, F. muralis*, C. benghalensis*, Xanthium strumarium ${ }^{*}$, T. majus*, S.oleraceus* ${ }^{*}$ E. plantagineum* ${ }^{*}$, C. dactylon.

Dominant species: P. australis, P. lapathifolia*.

The Phragmites community occurs within an altitudinal range between $5 \mathrm{~m}$ and $10 \mathrm{~m}$, primarily adjacent to agricultural and grazing lands in the lower reaches of the river, as well as some untransformed lands close to the river estuary. Soils are sandy with low resistivity, neutral $\mathrm{pH}$ (average $=6.80$ ), and high nutrient content. Similar to the Arundo community, the most prominent feature of this community is the dense thickets ( $3 \mathrm{~m}-5 \mathrm{~m}$ tall) formed by the dominant species, in this case $P$. australis. This community differs from the Arundo community, however, in that it contains a greater cover percentage of native species and is found further downstream. The tall herb P. lapathifolia (up to $1 \mathrm{~m}$ ) is often interspersed with $P$. australis, particularly in relevés further from the estuary. In some areas, portions of the $P$. australis thicket have been grazed down and $P$. clandestinum has taken hold, along with other non-native herbaceous species such as F. muralis, $C$. benghalensis and $X$. strumarium. This community often abuts the Salix community (see later) and, as such, S. mucronata subsp. mucronata occasionally overhangs the $P$. australis, providing minimal tree cover.

\section{Salix mucronata subsp. mucronata-Cyperus textilis community}

Abbreviated name: Salix community (Figure 3e).

Diagnostic species: S. mucronata subsp. mucronata, Z. aethiopica, Cynanchum obtusifolium, Cyperus textilis.

Constant taxa: T. fluminensis*, R. crispus*, R. rugosum*, P. clandestinum*, C. benghalensis*. 
Dominant species: S. mucronata subsp. mucronata, C. textilis, Cyperus dives, T. fluminensis*, T. majus*.

As mentioned earlier, this community often abuts the Phragmites community and is found in similar areas along the lower reaches of the river, at altitudes from $5 \mathrm{~m}$ to $15 \mathrm{~m}$. Soils are similarly sandy, with low resistivity, neutral $\mathrm{pH}$ (average $=6.83$ ), and high nutrient content. Native species dominate in this community, with an average absolute cover of $95 \%$ as compared with an average of $65 \%$ for alien species. The native $S$. mucronata subsp. mucronata forms a moderately tall (6 m-11 m) canopy above an otherwise heavily herbaceous community. Prominent understorey herbs include the alien T. fluminensis and native Z. aethiopica, with native C. obtusifolium occasionally twining through the branches of the S. mucronata subsp. mucronata. In some areas, S. mucronata subsp. mucronata tends to grow in dense, shrub-like patches. Thick clumps of $C$. textilis often intermingle with shrubby S. mucronata subsp. mucronata, creating a tangle of impenetrable vegetation.

\section{Ordination}

The results of the DCA ordination are graphically illustrated in Figure 4. The plant communities show very clear 'spatial' separation (with reference to the reduced multivariate space) along axes 1, 2 and 3, suggesting that the floristic-based classification was robust.

\section{Discussion}

This study provides the first description of riparian plant communities along the entire length of a river system in the CFR, including the many novel communities that now occur in the human-impacted riparian areas in this region. A study of this nature poses a particular challenge owing to the continually changing nature of many of these plant communities. This is especially true in urban and agricultural stretches of the river, which continue to be transformed by the proliferation of already present alien plant species and the incursion of new alien species.

The distribution of plant communities along the Eerste River is not determined by any single factor, but by the interaction of several environmental factors. It is difficult to separate the effects of environmental factors in a system that has been, and continues to be, so heavily transformed by human intervention. No single environmental component can be treated in isolation, although it appears that land use has played an important role in shaping the composition of plant communities. Those riparian areas where the landscape surrounding the river has been most heavily transformed by human factors are home to many of the novel plant communities dominated by alien species that are described in this paper, including the Bromus, Populus, Arundo, and Quercus communities. The relationship between alien plant species and surrounding land use was addressed in a separate study (Meek et al. 2010).
Owing to the extensive changes in soil nutrients and species composition that have occurred, complete restoration of these areas to their historic species assemblages (where this is known) is not feasible, and may even be detrimental (potentially leading to further degradation) in some cases. Steps can, however, be taken to remove some of the more aggressive alien species that are well established, whilst also re-introducing key native species into some communities (Galatowitsch \& Richardson 2005). Whilst it is impossible to know with certainty which native species dominated in these communities prior to human intervention, the native species that persist provide some clues. For instance, the Populus community, which now occurs along $30 \%$ of the Eerste River, has a number of native species that maintain a tenuous foothold in this novel community. These include the native trees S. mucronata subsp. mucronata, O. europaea subsp. africana and K. africana, all of which provide valuable ecosystem services to both humans and wildlife (Holmes et al. 2008; Richardson \& Fraser 1995; Venter \& Venter
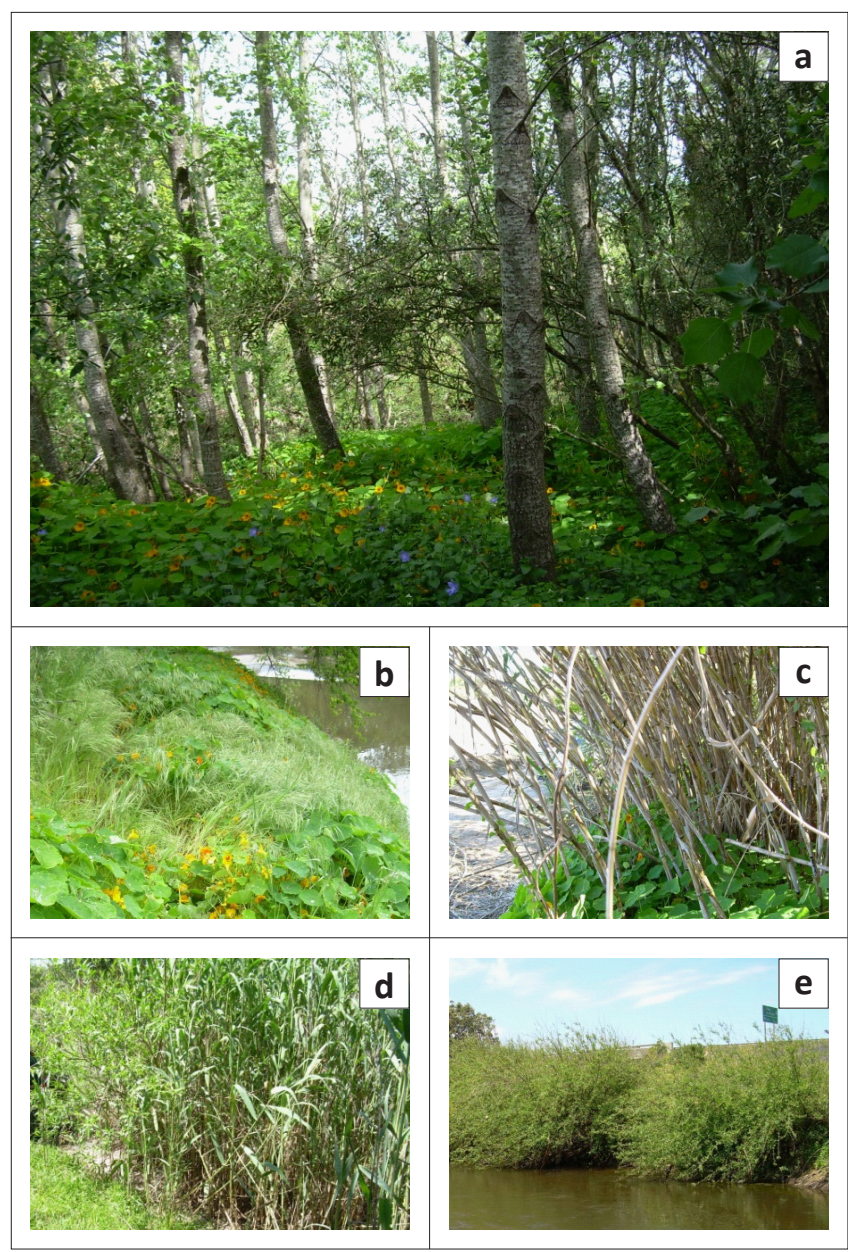

FIGURE 3: Plant communities along the lower reaches of the Eerste River (e.g. primarily downstream of the Plankenburg River confluence): (a) Populus community. Tall Populus $x$ canescens towers above a herbaceous understorey of Tropaeolum majus and Vinca major, with Olea europea subsp. africana and Kiggelaria africana in the middle shrub layer; (b) Bromus community with Tropaeolum majus and Bromus diandrus in the foreground; (c) Arundo community showing dense thicket of Arundo donax with Tropaeolum majus in the understory and Anredera cordifolia climbing the Arundo stalks; (d) Phragmites community showing dense thicket of Phragmites australis, with Salix mucronata subsp. mucronata and Pennisetum clandestinum present on the left and (e) Salix community showing bushy patches of Salix mucronata subsp. mucronata. 
1996). It is likely that the dense understorey of T. majus and T. fluminensis within the Populus community has suppressed the germination of native seedlings of these species, but they seem able to thrive below a canopy of $P . x$ canescens. Consequently, active planting will be necessary to establish denser stands of native vegetation, but little maintenance other than managing the invasive species may be necessary following these initial restoration activities. Once native species have grown large enough to provide the necessary soil stabilisation, $P$. $x$ canescens and other alien trees could be removed in order to provide a greater opportunity for native species to thrive.

There is an even greater opportunity for restoration along portions of the river dominated by the Quercus community, as a diverse array of native plant species persist amidst the alien species here. In fact, there is considerable overlap between native species in the Brabejum community and those in the Quercus community, including species such as

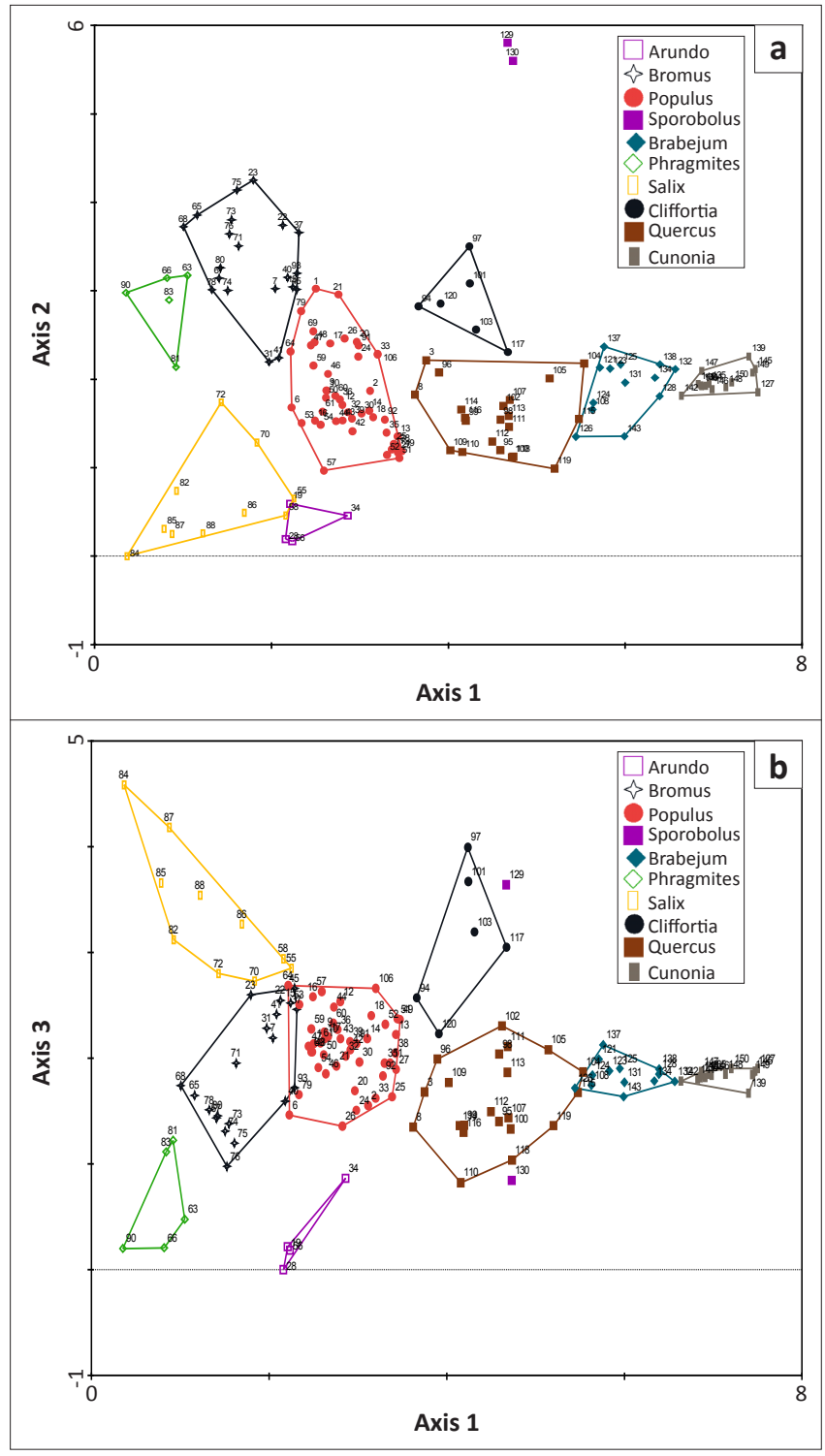

FIGURE 4: Detrended correspondence analysis ordination of the riparian vegetation plots showing positions of the 10 plant communities along axes (a) 1 and 2 and (b) 1 and 3 .
B. stellatifolium, M. angustifolia, P. serratum, and F. lanceolata. This, combined with the observation that these two communities exist both adjacent to and interspersed with each other, suggests that the Quercus community may have historically looked very similar to the Brabejum community. As such, land managers interested in restoring portions of the riparian habitat dominated by the Quercus community can consider the composition of the Brabejum community to discover suitable species for restoration activities. The most appropriate inventory of native species for restoration along a particular stretch of river could further be confirmed by scanning upstream and downstream vegetation for key native species in these areas.

The Quercus community exists as far downstream as the confluence with the Plankenburg River, below which the Populus community becomes dominant. Interspersed with the Populus community is the Arundo community, which is relatively rare along the river. The reed species A. donax is highly invasive and has major impacts in many Mediterranean-type ecosystems (Brooks et al. 2004; Coffman, Ambrose \& Rundel 2010; Gaertner et al. 2009). Efforts should be made to remove this species whilst it still occurs along only a small section of the Eerste River. Arundo donax tends to crowd out all other species, creating monospecific stands and providing few, if any, of the ecosystem services that other alien species may provide.

Interspersed with both the Populus and Salix communities is the Bromus community. As with the Arundo community, this community is in need of active restoration along the Eerste River. The Bromus community exists as a result of extensive clearing of woody vegetation by landowners and intensive grazing along portions of the lower river. This has left the river in these areas extremely vulnerable to erosion and sedimentation, adding to the river's already poor water quality in downstream areas. Where this community occurs in communal grazing lands, the appropriate species for restoration can be found amongst the native species in the Salix community, primarily S. mucronata subsp. mucronata and $C$. textilis. In these cases, the riparian area will need to be fenced or otherwise protected from grazing until the plants are of such a size that grazing will not disturb them. This could probably be achieved over one or two growing seasons, given the rapid growth of these species. Once these species have established themselves along the riverbank, they will provide not only numerous ecosystem services but also additional forage for cattle being grazed in the area. In other areas of the river where this community exists, the appropriate species for restoration will depend on adjacent communities. Where it exists interspersed with the Populus community, the appropriate species for restoration will be those listed earlier for the Populus community; where it exists adjacent to the Quercus community, the appropriate species for restoration can be found amongst the native species in the Brabejum or Cliffortia communities.

No other study from South Africa has shown such distinct differences amongst riparian plant communities as we 
have revealed in the current study. In fact, other studies of riparian communities (e.g. Prins et al. 2004) tended to show an overlapping continuum of plant communities rather than a series of unique communities with distinct differences. This is largely because previous studies were confined to riparian communities of headwater systems, where most native vegetation is intact and there is little human interference. Invasion by alien plant species and a range of humanmediated habitat modifications in downstream areas of the Eerste River have radically changed vegetation structure and composition (Meek et al. 2010). This has created an extensive array of novel plant communities, effectively disrupting the natural continuous vegetation patterns through increased local dominance and associated disassembly processes. However, even the two primarily native plant communities (those dominated by Brabejum and Cunonia), limited to the upper reaches of the river, were quite distinct on the axes of the DCA. Whilst these communities share many floristic similarities, they are structurally quite different. Had the species structural data layers been combined into a single layer, these two communities would likely have overlapped to a much greater extent in the diagram, and would not have been as distinct in the initial cluster analyses. Of the 10 plant communities, the Brabejum and Cunonia communities were also the most tightly clustered in the ordination diagram, whilst the compositional attributes of other plant communities were quite diffuse. This attests to the ever evolving nature of the downstream plant communities, which continue to be changed and shaped by human activities in the surrounding landscape, as well as the major influence of humans on the hydrological regime of the river.

\section{Conclusion}

An important priority for biodiversity conservation in South Africa is the protection and management of riparian habitats, which have become increasingly valuable owing to the multitude of ecosystem services they supply. Appropriate management of these riparian areas depends largely upon knowledge of riparian plant communities so that informed decisions can be made regarding their management and restoration. This study details the extensive changes in plant species composition that have occurred in many portions of the Eerste River's riparian zone, and helps to further an understanding of how riparian plant communities in the Western Cape are changing as a result of anthropogenic activities. Furthermore, it provides key data on those native species that continue to persist within and adjacent to aliendominated communities and offers insights with regard to options for restoration. Additional research is needed to determine long-term goals for the riparian vegetation along the Eerste River. All stakeholders need to be consulted to establish achievable goals. The results of this study provide important baseline information to guide management aimed at delivering sustainable ecosystem services.

\section{Acknowledgments}

Support for this work was provided by the DST-NRF Centre of Excellence for Invasion Biology. We thank Suzaan
Kritzinger-Klopper and Donald Iponga for assistance and companionship in the field, Terry Trinder-Smith for help with identifying plant specimens, Christy Momberg and Mathilda van der Vyver for administrative support, Lubomír Tichý for help with the JUICE software program, and the many landowners along the Eerste River, who kindly allowed us access to their land. C.S.M. also thanks the staff and students at the Percy FitzPatrick Institute for their support during the study. CapeNature kindly provided the plant collection permits.

\section{Competing interests}

The authors declare that they have no financial or personal relationship(s) that may have inappropriately influenced them in writing this article.

\section{Authors' contributions}

C.S.M. (University of Cape Town) and D.M.R. (Stellenbosch University) were responsible for writing of the manuscript, C.S.M. was responsible for vegetation sampling and data analysis and L.M. (Stellenbosch University) assisted with the ordination analysis and classification of plant communities. D.M.R. provided overall project guidance.

\section{References}

Bray, R.H. \& Kurtz, L.T., 1945, 'Determination of total, organic, and available forms of phosphorus in soils', Soil Science 59, 39-45. http://dx.doi.org/10.1097/00010694194501000-00006

Bromilow, C., 2005, Problem plants of South Africa, Briza Publications, Pretoria.

Brooks, M.L., D’Antonio, C.M., Richardson, D.M., Grace, J.B., Keeley, J.E., DiTomaso, J.M. et al., 2004, 'Effects of invasive alien plants on fire regimes', Bioscience 54 677-688. http://dx.doi.org/10.1641/0006-3568(2004)054[0677:EOIAPO]2.0.CO;2

Brown, C., 1998, 'The ecological status of Western Cape rivers investigated: Shock survey findings', African Wildlife 52, 27-28.

Brown, C.A. \& Dallas, H.F., 1995, Eerste River, Western Cape: Situation assessment of the riverine ecosystem. Final report, June 1995, Southern Waters Ecological Research and Consultancy, CSIR, Stellenbosch.

Brown, C.A. \& Magoba, R., 2009, 'Rivers and wetlands of Cape Town', Report No. TT 376/08, Water Research Commission, Pretoria.

Campbell, B.M., 1986, 'Montane plant communities of the fynbos biome', Vegetatio 66, 3-16. http://dx.doi.org/10.1007/BF00044078

Chytrý, M., Tichý, L., Holt, J. \& Botta-Dukát, Z. 2002, 'Determination of diagnostic species with statistical fidelity measures', Journal of Vegetation Science 13, 79-90. http://dx.doi.org/10.1111/j.1654-1103.2002.tb02025.x

Coffman, G.C., Ambrose, R.F. \& Rundel, P.W., 2010, 'Wildfire promotes dominance of invasive giant reed (Arundo donax) in riparian ecosystems of Mediterranean-type
climate regions', Biological Invasions 12, 2723-2734. http://dx.doi.org/10.1007/ s10530-009-9677-z

Cowling, R.M. (ed.), 1992, The ecology of fynbos. Nutrients, fire and diversity, Oxford University Press, Cape Town.

Cowling, R.M. \& Holmes, P.M., 1992, 'Flora and vegetation', in R.M. Cowling (ed.), The ecology of fynbos: Nutrients, fire and diversity, pp. 23-61, Oxford University Press, Cape Town.

Cowling, R.M., Richardson, D.M. \& Mustart, P.J., 1997, 'Fynbos', in R.M. Cowling, D.M. Richardson \& S.M. Pierce (eds.), Vegetation of southern Africa, pp. 99-130, Cambridge University Press, Cambridge.

Department of Water Affairs and Forestry (DWAF), 1993, 'Western Cape System Analysis. Water Quality, Volume 1: General', Report No. P G000/00/2891, Cape Town.

Department of Water Affairs and Forestry (DWAF), 2004. 'Berg Water Management Area: Internal Strategic Perspective', Report No. P WMA 19/000/00/0304 Pretoria.

Foxcroft, L.C., Rouget, M. \& Richardson, D.M., 2007, 'Risk assessment of riparian plant invasions into protected areas', Conservation Biology 21, 412-421. http://dx.doi. org/10.1111/j.1523-1739.2007.00673.x, PMid:17391191

Gaertner, M., Den Breeÿen, A., Hui, C. \& Richardson, D.M., 2009, 'Impacts of alien plant invasions on species richness in Mediterranean-type ecosystems: A meta-analysis', Progress in Physical Geography 33, 319-338. http://dx.doi. org/10.1177/0309133309341607 
Galatowitsch, S.M. \& Richardson, D.M., 2005, 'Riparian scrub recovery after clearing of invasive alien trees in headwater streams of the Western Cape, South Africa', Biological Conservation 122, 509-521. http://dx.doi.org/10.1016/j. biocon.2004.09.008

Goldblatt, P. \& Manning, J.C., 2000, Cape plants: A conspectus of the Cape Flora of South Africa, National Botanical Institute, Pretoria.

Henderson, L., 2001, Alien weeds and invasive plants: A complete guide to declared weeds and invaders in South Africa, Agricultural Research Council, Pretoria (ARCPPRI, PPRI Handbook No. 12).

Hill, M.O. \& Gauch, Jnr., H.G., 1980, 'Detrended correspondence analysis: An improved ordination technique', Vegetatio 42, 47-58. http://dx.doi.org/10.1007/ BF00048870

Hobbs, R.J., Arico, S., Aronson, J., Baron, J.S., Bridgewater, P., Cramer, V.A. et al., 2006, 'Novel ecosystems: Theoretical and management aspects of the new ecological world order', Global Ecology and Biogeography 15, 1-7. http://dx.doi. org/10.1111/j.1466-822X.2006.00212.x

Holmes, P.M., Esler, K.J., Richardson, D.M. \& Witkowski, E.T.F., 2008, 'Guidelines for improved management of riparian zones invaded by alien plants in South Africa', South African Journal of Botany 74, 538-552. http://dx.doi.org/10.1016/j. sajb.2008.01.182

Holmes, P.M., Richardson, D.M., Esler, K.J., Witkowski, E.T.F. \& Fourie, S., 2005, 'A decision-making framework for restoring riparian zones degraded by invasive alien plants in South Africa', South African Journal of Science 101, 553-564.

Hood, W.G. \& Naiman, R.J., 2000, 'Vulnerability of riparian zones to invasion by exotic vascular plants', Plant Ecology 148, 105-114. http://dx.doi. org/10.1023/A:1009800327334

King, J.M., 1981, 'The distribution of invertebrate communities in a small South African river', Hydrobiologia 83, 43-65. http://dx.doi.org/10.1007/BF02187150

Kruger, F.J., 1978, 'A description of the Fynbos Biome Project', South African National Scientific Programmes Report 28. CSIR, Pretoria.

Linder, H.P., 2003, 'The radiation of the Cape flora, southern Africa', Biological Reviews 78, 597-638. http://dx.doi.org/10.1017/S1464793103006171, PMid:14700393

Linder, H.P., Meadows, M.E. \& Cowling, R.M., 1992, 'History of the Cape flora', in R.M Cowling, (ed.), The ecology of fynbos: Nutrients, fire and diversity, pp. 113-134, Oxford University Press, Cape Town.

Manders, P.T. \& Richardson, D.M., 1992, 'Colonization of Cape fynbos communitie by forest species', Forest Ecology and Management 48, 277-293. http://dx.doi. org/10.1016/0378-1127(92)90150-8

McDonald, D.J., 1988, 'A synopsis of the plant communities of Swartboschkloof, Jonkershoek, Cape Province', Bothalia 18, 233-260.

Meek, C.S., Richardson, D.M. \& Mucina, L., 2010, 'A river runs through it: Land-use and the composition of vegetation along a riparian corridor in the Cape Floristic Region, South Africa', Biological Conservation 143, 156-164. http://dx.doi. org/10.1016/j.biocon.2009.09.021

Moffett, R.O., 2007, 'Name changes in the Old World Rhus and recognition of Searsia (Anacardiaceae)', Bothalia 37, 165-175.

Olsen, S.R., Cole, C.V., Watanabe, F.S. \& Dean, L.A., 1954, 'Estimation of available phosphorus in soils by extraction with sodium bicarbonate', USDA Circular 939, $1-19$.
Planty-Tabacchi, A., Tabacchi, E., Naiman, R.J., Deferrari, C. \& Decamps, H., 1996 'Invasibility of species-rich communities in riparian zones', Conservation Biology 10, 598-607. http://dx.doi.org/10.1046/j.1523-1739.1996.10020598.x

Prins, N., Holmes, P.M. \& Richardson, D.M., 2004, 'A reference framework for the restoration of riparian vegetation in the Western Cape, South Africa, degraded by invasive Australian Acacias', South African Journal of Botany 70, 767-776.

Pyšek, P., Richardson, D.M., Rejmánek, M., Webster, G.L., Williamson, M. \& Kirschner, J., 2004, 'Alien plants in checklists and floras: Towards better communication between taxonomists and ecologists', Taxon 53, 131-143. http://dx.doi. org $/ 10.2307 / 4135498$

Richardson, D.M. \& Fraser, M.W., 1995, 'Birds of Swartboskloof, Jonkershoek Valley, Stellenbosch: A mountain fynbos habitat', Southern Birds 18, 1-44.

Richardson, D.M., Holmes, P.M., Esler, K.J., Galatowitsch, S.M., Stromberg, J.C., Kirkman, S.P. et al., 2007, 'Riparian vegetation: degradation, alien plant invasions, and restoration prospects', Diversity and Distributions 13, 126-139. http://dx.doi. org/10.1111/j.1366-9516.2006.00314.x

Rouget, M., Cowling, R.M., Pressey, R.L. \& Richardson, D.M., 2003, 'Identifying spatia components of ecological and evolutionary processes for regional conservation planning in the Cape Floristic Region, South Africa', Diversity and Distributions 9 191-210. http://dx.doi.org/10.1046/j.1472-4642.2003.00025.x

Sieben, E.J.J., 2003, 'The riparian vegetation of the Hottentots Holland Mountains', $\mathrm{PhD}$ Dissertation, University of Stellenbosch.

Sieben, E.J.J., Mucina, L. \& Boucher, C., 2009, 'Scaling hierarchy of factors controlling riparian vegetation patterns of the Fynbos Biome at the Western Cape, South Africa', Journal of Vegetation Science 20, 17-26. http://dx.doi.org/10.1111/ j.1654-1103.2009.03989.x

Sieben, E.J.J. \& Reinecke, M.K., 2008, 'Description of reference conditions for restoration projects of riparian vegetation from the species-rich Fynbos biome' South African Journal of Botany 74, 401-411. http://dx.doi.org/10.1016/j. sajb.2008.01.176

Taylor, H.C., 1978, 'Capensis', in M.J.A. Werger (ed.), The biogeography and ecology of southern Africa, pp. 171-230, W. Junk, The Hague. http://dx.doi.org/10.1007/97894-009-9951-0_8

Ter Braak, C.J.F. \& Šmilauer, P. 2002, CANOCO 4.5 Reference manual and CanoDraw for Windows User's guide: Software for canonical community ordination, Microcomputer Power, Ithaca, NY.

Tichý, L., Chytrý, M. \& Zelený, D., JUICE Version 7.0, computer software, viewed n.d. from http://www.sci.muni.cz/botany/juice.htm

Van Wilgen, B.W. \& Kruger, F.J., 1985, 'The physiography and fynbos vegetation communities of the Zachariashoek catchments, southwestern Cape Province, South African Journal of Botany 51, 379-399.

Venter, F. \& Venter, J., 1996, Making the most of indigenous trees, Briza Publications, Pretoria.

Walkley, A., 1935, 'An examination of methods for determining organic carbon and nitrogen in soils', Journal of Agricultural Science 25, 598-609. http://dx.doi. org/10.1017/S0021859600019687

Westhoff, V. \& Van der Maarel, E., 1973, 'The Braun-Blanquet approach', in R.H. Whittaker (ed.), Ordination and classification of communities, pp. 617-726, W. Junk, The Hague. http://dx.doi.org/10.1007/978-94-010-2701-4_20 